\title{
PERILAKU AGRESIF EKSEKUTIF DALAM KECURANGAN PELAPORAN KEUANGAN
}

\author{
Yasmi, SE, M.Si, Ak. NIDN: 0925107801 \\ Siprianus Palete, SE, M.Si, Ak. NIDN ; 0922097303
}

\begin{abstract}
ABS TRACT
The practice accounting expands along with blooming economics. One of the existences of growth of practice accounting is fraud accounting. There are some creative logical reasons used by perpetors as basis for applying fraud accounting.Fraud accounting is the process of intentionally misrepresenting a company's finances look better than what they really are. To identify the management role as the actors in fraud accounting, it is need a deep understanding of driving factors that lead to financial misdeeds.
\end{abstract}

Keywords: fraud accounting, intentionally misrepresenting, financial mesdeeds.

\section{PENDAHULUAN}

Segitiga kecurangan telah dibakukan sebagai faktor-faktor resiko yang harus diwaspadai dalam standar pemeriksaan akuntansi berdasarkan International Standards on Auditing (ISA) No. 240 dan Generally Accepted Auditing Standards (GAAS) No. 316. Faktor-faktor resiko tersebut merupakan perilaku manajemen atau karyawan atau pihak ketiga yang tidak etis dalam menjalankan bisnis. Keterlibatan manajemen dalam kecurangan laporan keuangan dapat terjadi bukan hanya karena dorongan kompetisi tetapi dapat juga dipengaruhi oleh hasrat manusiawi dan pembenaran diri.

Dalam pengertian yang luas, fraud diartikan sebagai tindakan menipu atau salah merepresentasikan kebenaran yang mempengaruhi pihak lain untuk melepaskan suatu nilai atau hak hukumnya. Arti fraud secara spesifik dapat saja berubah sejalan dengan perubahan lingkungan yang di dalamnya terdapat orang-orang dengan standar kebenaran dan keadilan yang berbeda. Seseorang dapat melakukan sesuatu secara benar, tetapi juga dapat berperilaku tidak rasional yang menghasilkan ide dan tindakan yang salah. Ketidakbenaran dapat terjadi karena kesalahan, salah informasi, salah hitung atau kelalaian. Kasus- 
kasus fraud terbangun atas dasar ketidakeadilan dan ketidakjujuran. The International Standards on Auditing (ISA) ${ }^{1}$ mendefinisikan fraud sebagai:

"An intentional act by one or more individuals among management, those charged with governance, employees, or third parties, involving the use of deception to obtain an unjust or illegal advantage".

Meskipun semua tipe fraud itu penting, fokus tulisan ini didasarkan pada management fraud. Fraud jenis ini didefinisikan oleh Sigleton at al., 2006, sebagai the intentional misrepresentation of corporate or unit performance levels perpetrated by employees serving in management roles who seek to benefit from such frauds in terms of promotions, bonuses or other economic incentives, and status symbols.

\section{Rumusan Masalah}

Teori fraud klasik membantu memberikan pemahaman tentang mengapa kecurangan laporan keuangan terjadi. Teori ini dapat digunakan oleh pemegang saham, direksi dan pihak lain untuk mengerti isu-isu kemerosotan etika untuk menyiapkan diri mereka menghadapi perilaku curang dalam perusahaan. Seperti halnya dalam teori kecurangan klasik, standar audit juga memberikan petunjuk tentang faktor-faktor resiko kecurangan, yang disebabkan oleh insentif atau tekanan (incentives and pressures) untuk melakukan kecurangan, adanya kesempatan (opportunities), dan beberapa tindakan rasionalisasi (rationalization). Oleh karena itu, terdapat kebutuhan mengidentifikasi elemenelemen yang terkandung dalam teori fraud triangle yang mempengaruhi intensi manajemen perusahaan untuk melakukan kecurangan. Bentuk kecurangan laporan keuangan kelihatannya sangat mudah terjadi bila manajemen mempunyai insetif seperti bonus, pemilikan bagian saham dan juga tekanan analis dan pelaku pasar. Peluang manajemen untuk melakukan kecurangan meningkat jika tata kelola dan pengendalian internal perusahaan lemah, dan akhirnya, rasionalisasi diungkapkan sebagai pembenaran perilaku curang oleh manajemen.

\footnotetext{
${ }^{1}$ www.ifac.org
} 


\section{AKUNTANSI KECURANGAN (FRAUD ACCOUNTING)}

Menjawab pertanyaan mengapa top management memutuskan untuk untuk terlibat dalam ketidaketisan atau kecurangan pelaporan keuangan, akan mencakup banyak hal, mulai dari pembahasan psikologis, kriminologi, akuntansi hingga permasalahan hukum. Mungkin kecurangan dapat diidentifikasi berdasarkan atribut lingkungan, organisasi dan individu jika diasosiasikan dengan pelanggaran terhadap prinsip akuntansi, tetapi beberapa atribut dalam manajemen laba tidak dapat dikategorikan sebagai pelanggaran terhadap prinsip akuntansi. Hal yang sulit untuk diidentifikasi ketika membicarakan motif, kepribadian atau kombinasi antara keinginan perorangan dengan organisasi untuk melakukan pelanggaran tidak etis dalam pelaporan keuangan. Beberapa model penjelasan (explanatory model) yang telah diteliti akan penulis uraikan di bawah ini.

Studi berdasarkan theory of planned behavior dilakukan oleh Magnan et al., 2008, menganalisis tata kelola perusahaan, pengendalian dan peran manajer. Penelitian ini melihat kembali proses dinamis kecurangan laporan keuangan yang dilakukan oleh para pemimpin perusahaan, terutama menginvestigasi bagaimana dan mengapa seorang pemimpin perusahaan terlibat dalam kecurangan dan bagaimana auditor dan regulator membutuhkan tinjauan ulang atas pendekatan analitis untuk mendeteksi kecurangan. Penelitian ini menggarisbawahi kepercayaan diri manajemen yang dapat meningkat hingga memperbesar perilaku curang dalam perusahaan. Dalam pandangan mereka, media dan analis berperan melambungkan kepercayaan diri manajemen. Peningkatan kepercayaan diri dan perasaan berkuasa melalui liputan media dan pendapat para analis akan memacu manajemen mengambil langkah beresiko dalam aktivitas kecurangan untuk mempertahankan reputasinya. Penelitian yang dilakukan terhadap 15 perusahaan bermasalah di Canada ini juga menemukan bahwa struktur kepemilikan juga mempengaruhi kemampuan pemimpin perusahaan untuk melakukan kecurangan laporan keuangan.

Gillett and Uddin, 2005, berusaha untuk menjelaskan dinamika ketidaketisan dan kecurangan laporan keuangan dengan menggunakan sudut pandang psikologi yakni melalui teori reasoned action untuk memprediksi intensi 
pribadi dan hubungannya dengan perilaku. The theory of reasoned action mengasumsikan bahwa manusia adalah rasional dan menggunakan informasi dengan cara yang sistematis dengan mempertimbangkan segala implikasi tindakan mereka sebelum memutuskan untuk berlaku dengan cara tertentu. Gillet dan Uddin menekankan bahwa sikap individu (keyakinan dan kebutuhan pencapaian) struktur kompensasi, ukuran perusahaan dan norma-norma subyektif yang berasal dari referent group sangat kuat mendorong para direktur keuangan untuk terlibat dalam kecurangan laporan keuangan.

\section{Segitiga Kecurangan (Fraud Triangle)}

Teori kecurangan klasik, Cressey, 1953, menjelaskan alasan keterlibatan seseorang terlibat dalam kecurangan laporan keuangan dan atau bentuk kecurangan lainnya. Teori ini menyatakan bahwa individu terlibat dalam kecurangan sebagai akibat dari fraud triangle yang uraikan sebagai 1) pressure (tekanan) atau insentif atau motivasi dan biasanya merupakan kebutuhan yang tidak dapat dibagi; 2) opportunity ( peluang ) dan pengetahuan untuk melakukan kecurangan; 3) attitude/rationalization - perilaku atau rasionalisasi.

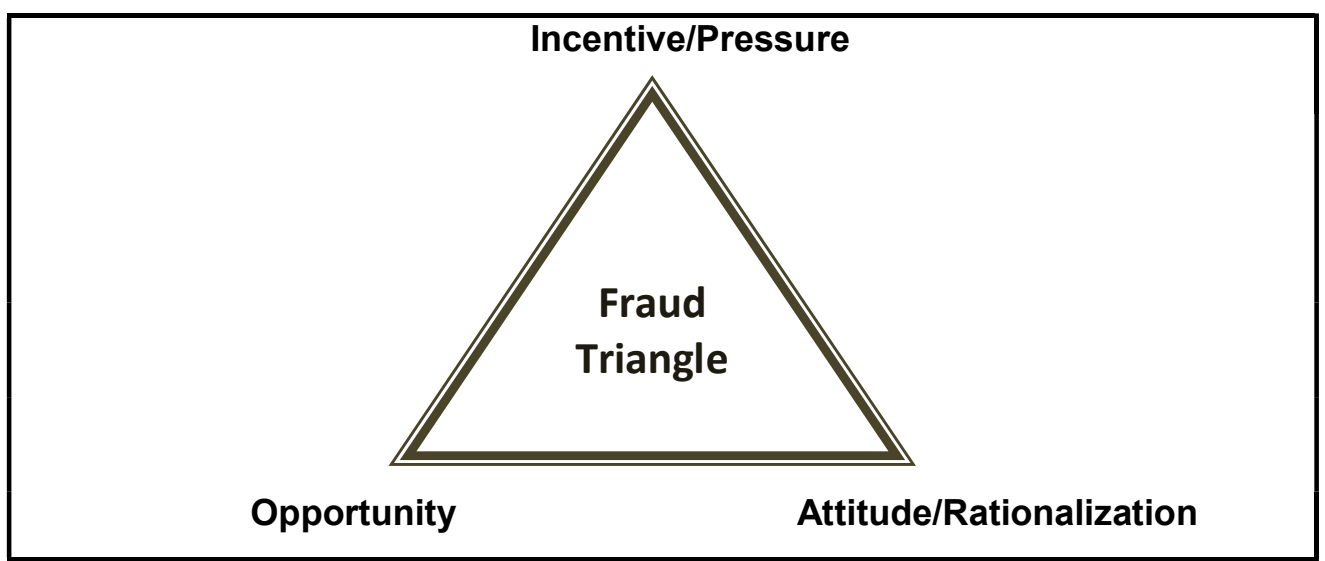

Gambar 1: Fraud Triangle

Elemen pertama dari fraud triangle adalah tekanan (pressure). Setiap pelaku kecurangan biasanya menghadapi semacam tekanan. Kebanyakan tekanan biasanya berupa kebutuhan keuangan yang merupakan motif untuk 
melakukan kecurangan seperti keserakahan, kebutuhan untuk melaporkan pencapaian yang lebih baik, kefrustrasian dalam bekerja, bahkan tantangan untuk melawan sistem, atau juga ketakutan. Kebutuhan akan uang dapat disebabkan oleh penggunaan obat-obatan terlarang, ketagihan alkohol, perjudian dan ketergantungan seksual atau pola hidup mewah seseorang. Kegiatan politik seseorang dapat juga memicu terjadinya kecurangan termasuk pengambilan informasi dari organisasi (ACFE, 2007).

Motif lain yang dapat menimbulkan kecurangan dalam organisasi yaitu adanya kelompok yang ingin mendapat pengakuan sehingga terlibat dalam aktivitas kriminal. Supaya seorang karyawan diterima dalam suatu sub-budaya, maka ia harus mengambil bagian dalam pencurian dan kecurangan untuk diterima oleh sub-grup tertentu. Egoisme juga merupakan motif yang dapat dihubungkan dengan terjadinya pencurian atau kecurangan dalam organisasi. Seseorang dapat melakukan kecurangan sebagai kegemaran. Sebagian orang juga dapat mencuri dalam organisasi hanya untuk memperlihatkan bahwa mereka dapat mengalahkan sistem atau untuk membuktikan bahwa mereka lebih pintar dan lebih cerdas daripada sistem dalam organisasi.

Elemen kedua dalam fraud triangle adalah peluang (opportunity), yaitu lingkungan di mana individu merasa bahwa ia dapat terlibat dalam suatu aktivitas kriminal. Berbagai kondisi dalam lingkungan organisasi atau perusahaan yang dapat menjadikan individu merasa memiliki kesempatan untuk melakukan kecurangan. Kesempatan ini terjadi terutama karena lemahnya kebijakan pengendalian dalam organisasi, terutama kebijakan yang bersifat tertulis sebagai bentuk penegakan otoritas kekuasaan. Hal ini dapat berupa lemahnya sistem pengendalian, program bahkan orang-orang yang bekerja di dalamnya. Ini dapat dilihat oleh orang tertentu, tanpa diikuti oleh norma-norma sosial, sebagai suatu peluang untuk melakukan kecurangan (ACFE, 2007).

Elemen ketiga dalam fraud triangle adalah sikap/rasionalisasi (attitude/rationalization), untuk meredakan rasa bersalah pelaku. Setelah elemen motif/tekanan dan peluang, pelaku memerlukan langka terakhir dalam fraud triangle, sebagai langkah terakhir untuk membenarkan tindakan mereka. Rasionalisasi adalah metode dan proses mental di mana individu dapat 
memperoleh pengertian dalam pikirannya dan untuk menjustifikasi suatu tindakan dan kegiatan-kegiatan yang melibatkan dirinya.

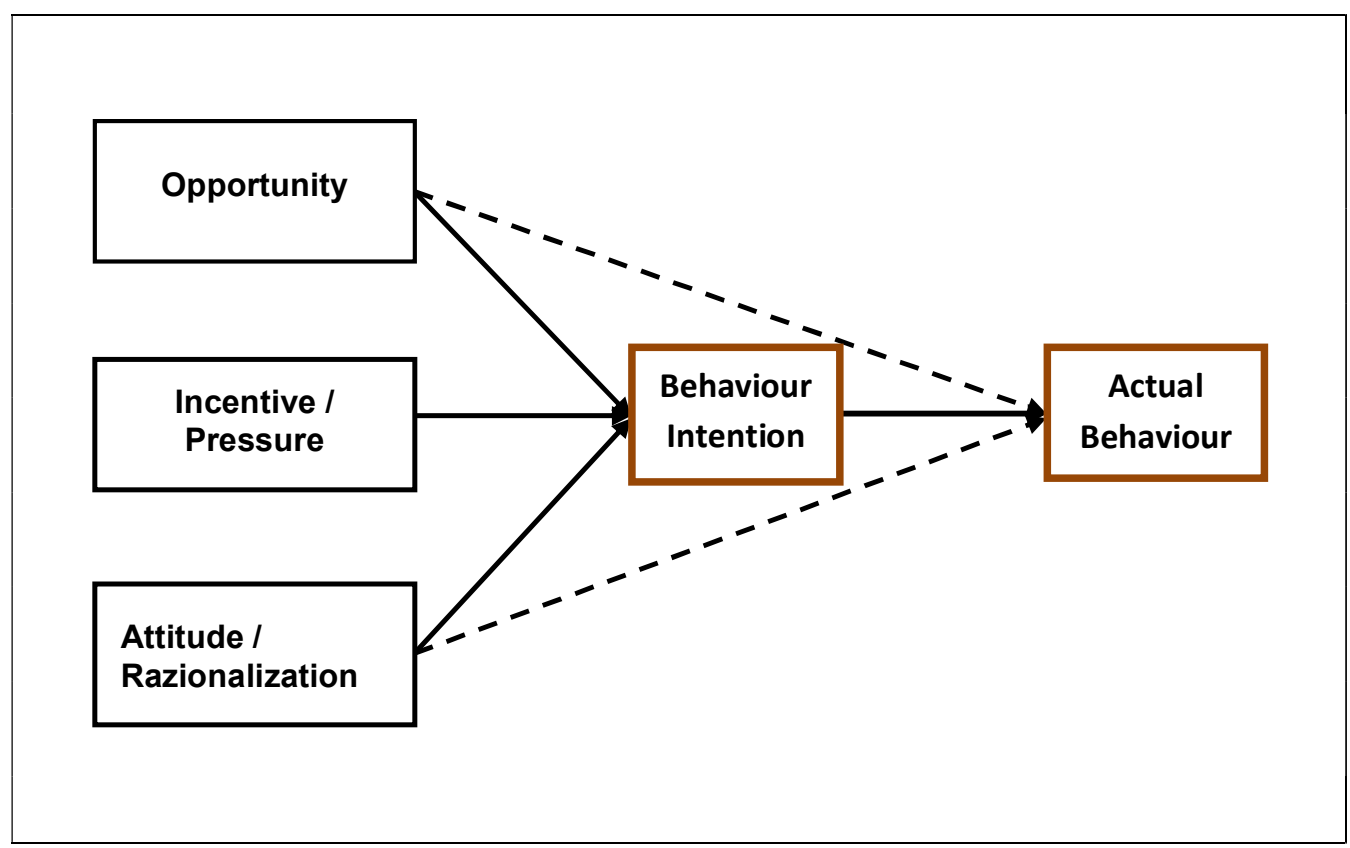

Gambar 2: Fraud Triangle dan Motivasi

\section{Metodologi Penelitian}

Dalam penelitian ini dilakukan dengan pendekatan interpretif dengan menggunakan data historis sebagai alat utama untuk menganalisis masalah penelitian. Penelitian ini sangat bergantung pada tinjauan literatur yang berhubungan dengan permasalahan dan kerangka penelitian yang dibangun. Berdasarkan tujuan dan pertanyaan penelitian, penulis menyimpulkan bahwa studi tentang perilaku manajemen dalam perusahaan yang menjadi bahasan dalam penelitian yang bersifat deskriptif interpretatif.

Penulis menggunakan data dari berbagai sumber dalam penelitian ini. Sumber data terutama yaitu berupa buku dan artikel serta jurnal yang berhubungan dengan penelitian ini. Data- data online banyak diperoleh dengan mengakses internet terutama untuk mencari data yang relevan dengan kecurangan perusahaan yang yang dibangun dari keinginan manajemen. Data- 
data tersebut kemudian diinterpretasikan untuk mengetahui proses terjadinya kecurangan perusahaan.

Sampel penelitian ini terdiri dari tiga kasus besar kecurangan laporan keuangan yang terjadi di Amerika Serikat. Perusahaan-perusahaan tersebut dipilih dari The Corporate Scandals Sheet yang dirilis situs www.forbes.com, yang CEOnya merupakan salah satu dari the Top 10 Crooked CEO yang dirilis majalah Time. Perusahaan yang dipilih berasal dari industri yang berbeda, yaitu kecurangan yang terjadi di Adelphia Communications (TV Kabel), Tyco International (alat-alat keselamatan dan kebakaran), dan WorldCom (telekomunikasi). Ketiga kasus kecurangan ini telah dijatuhi sanksi dan denda oleh badan otoritas, serta pelaku yang terlibat dalam kecurangan pada masingmasing perusahaan telah dijatuhi hukuman yang berkekuatan tetap oleh pengadilan di Amerika Serikat. Peneliti menginterpretasi perilaku berdasarkan dokumen ketiga kasus skandal korporasi tersebut dengan menggunakan bukti yang dikumpulkan dari buku, artikel, jurnal, dan pernyataan lembaga regulator.

Alat analisis data yang digunakan untuk menarik kesimpulan dalam penelitian ini yaitu dengan mengklasifikasikan jenis penyimpangan ke dalam faktor-faktor resiko kecurangan berdasarkan fraud triangle yang terdapat dalam lampiran ISA No. 240 tahun 2004 (adopted by UK \& Ireland).

\section{PEMBAHASAN}

\section{Skema Kecurangan Laporan Keuangan}

Kecurangan laporang keuangan dapat terjadi dalam berbagai bentuk, tetapi terdapat beberapa metode yang umumnya digunakan oleh para pelaku. Metode yang umumnya digunakan yaitu pendapatan fiktif, perbedaan waktu transaksi, pembatalan kewajiban dan biaya, pengungkapan yang salah, transaksi antar pihak yang berhubungan, dan penilaian aset yang tidak tepat. Jika dilihat dari perspektif akuntansi, kecurangan dilakukan dengan pengungkapan lebih tinggi atas pendapatan, laba dan aset, sedangkan pengungkapan lebih rendah dalam laporan keuangan dilakukan terhadap kerugian, biaya atau kinerja keuangan perusahaan. Pengungkapan lebih rendah terhadap kerugian, biaya dan kewajiban merefleksikan peningkatan dalam aset bersih dan ekuitas. 
Pengungkapan lebih rendah terhadap pendapatan dan pengungkapan lebih tinggi terhadap biaya mengindikasikan bahwa perusahaan ingin mengurangi kewajiban pajaknya. Kasus-kasus kecurangan terutama menggunakan skemaskema pengakuan pendapatan termasuk pendapatan fiktif dan perbedaan waktu pengakuannya.

Pendapatan fiktif (fictitious revenues). Pendapatan fiktif pada dasarnya merupakan pencatatan penjualan yang tidak terjadi. Pencatatan seperti ini dibuat atau dilakukan dengan memanipulasi transaksi untuk menjaga perusahaan tetap melaporkan penghasilan. Perekaan pendapatan biasanya dilakukan dengan menciptakan konsumen dan penjualan palsu. Pemalsuan penjualan dapat melibatkan konsumen yang terlegitimasi, tetapi pemalsuannya berupa penambahan tagihan atau dengan meningkatkan kuantitas dan harga terhadap konsumen bersangkutan. Pada periode berikutnya penjualan tersebut dikreditkan dengan jurnal balik. Perbedaan waktu juga digunakan untuk menciptakan pendapatan fiktif. Pengakuan pendapatan lebih awal sebelum direalisasi akan meningkatkan penghasilan. Biaya biasanya dikapitalisasi atau dicatat pada periode berikutnya sehingga tidak mempengaruhi laporan laba rugi berjalan. Depresiasi dan amortisasi juga dapat digunakan untuk memperlambat pengakuan biaya. Jika tujuannya adalah untuk mengurangi pendapatan agar dapat meminimalkan pembayaran pajak, maka biaya akan dipercepat ke periode berjalan. Percepatan depresiasi dan amortisasi dilakukan dengan miningkatkan tarif depresiasi dan amortisasi aset atau membiayakan belanja modal. Pendapatan fiktif sebesar USD 7.1 miliar ditemukan di WorldCom yang terjadi dari tahun 1999 hingga kuarter pertama tahun 2002 sebagai akibat dari tekanan untuk terus memproduksi laba dan intensi untuk terlihat sukses agar dapat menarik perhatian para investor.

\section{Penyembunyian Kewajiban atau Biaya (Consealed Liabilities/}

Expenses). Penyembunyian kewajiban atau biaya dalam perusahaan dilakukan oleh manajemen untuk menggelembungkan ekuitas, aset dan laba bersih perusahaan. Hal-hal lain yang dilakukan untuk menyembunyikan kewajiban adalah dengan melaporkan kewajiban lebih rendah dari nilai yang sebenarnya dilakukan dengan tidak mencatat hutang atau kewajiban akrual, mencatat 
pendapatan yang belum diperoleh sebagai pendapatan yang telah diperoleh, tidak mencatat jaminan, pinjaman atau kewajiban kontingensi. Penyembunyian biaya ini dilakukan Adelphia dengan mengeluarkan pinjaman bank sejumlah USD 2,3 juta dari laporan keuangan dan menjadikannya sebagai kewajiban di luar neraca Adelphia.

Transaksi Pihak yang Berhubungan (Related-party Transactions). Transaksi antar pihak yang berhubungan rawan untuk dimanipulasi. Manajemen dapat menggelembungkan nilai aset atau menurunkan kewajiban sebesar jumlah transaksi dari perusahaan afiliasi. Transaksi antar pihak yang berhubungan muncul melalui pembelian dari perusahaan afiliasi di atas harga pasar atau dengan mentranfer kewajiban kepada perusahaan afiliasi. SEC pada bulan September 2002 yang melaporkan bahwa CEO dan CFO Tyco memanipulasi dua program pinjaman perusahaan untuk mendapatkan pinjaman tanpa bunga dan pinjaman berbunga rendah yang akan digunakan untuk membeli rumah dan barang-barang antik.

Penilaian aset yang tidak tepat (improper asset valuation). Perusahaan menggunakan asetnya untuk menghasilkan uang dan membayar hutang-hutangnya. Aset yang paling sering dinilai secara tidak tepat yaitu persediaan, piutang dan aktiva tetap. Persediaan dicatat melalui transfer dari proses pabrikasi yang cukup rumit dan pemindahan lokasi persediaan memudahkan pelaku kecurangan untuk mengestimasi dan memperlambat pencatatan persediaan secara tidak tetap. Persediaan juga dapat diperlambat pemindahaannya untuk memanipulasi jumlah fisiknya, mencatat persediaan fiktif, menggagalkan pembelian persediaan dan untuk mengkapitalisasi persediaan.

Piutang dimanipulasi dengan cara yang sama dengan manipulasi pendapatan dan persediaan. Piutang fiktif dibuat untuk memberikan kesan dalam laporan keuangan bahwa perusahaan sukses dalam penjualan. Sedangkan aktiva tetap dimanipulasi melalui pencatatan aset fiktif, merepresentasikan nilai aset secara tidak benar, kapitalisasi aset yang salah atau salah mengklasifikasi aset. Aset fiktif biasanya diklasifikasi menjadi aset pemilik atau dengan melampungkan nilai aset terutama antar pihak yang berhubungan. Salah klasifikasi aset dilakukan dengan mengkapitalisasi non-aset menjadi aktiva tetap. 
Kapitalisasi aset ini misalnya dilakukan oleh WorldCom, yakni ketika internal audit pada bulan Agustus 2002 melaporkan adanya pencatatan yang salah sebesar USD 3,3 miliar laba yang terjadi dari tahun 1999 hingga kuarter pertama tahun 2002. Jumlah ini merupatan tambahan terhadap USD 3,8 miliar biaya yang salah dilaporkan sebagai investasi modal pada tahun 2001.

\section{Kecurangan berdasarkan Teori Fraud Triangle}

Kecurangan merupakan masalah global yang mempengaruhi semua tingkat dan ukuran organisasi. Karena itu organisasi harus selalu berusaha secara terus menerus untuk mengidentifikasi motif dan metode yang dilakukan oleh pelaku kecurangan agar dapat mendesain program anti kecurangan untuk mencegah, mendeteksi dan mengidentifikasi aktifitas kecurangan. Manajemen resiko kecurangan diperlukan untuk mengidentifikasi tingkat kerawanan, pengurangan kecurangan secara proaktif dan memonitor faktor-faktor pendorong aktivitas kecurangan. Cara terbaik untuk mencegah kecurangan yaitu bahwa internal auditor harus mengerti mengapa orang melakukan kecurangan. Pengertian tentang kecurangan umumnya didorong oleh tekanan akan adanya kebutuhan, kesempatan dan rasionalisasi terhadap perilaku kecurangan. Rasionalisasi aktivitas kecurangan ini lebih banyak dipengaruhi oleh sikap individu dalam menanggapi isu-isu dalam lingkungan kerja dan kemampuan individu itu untuk mengendalikan dirinya terhadap tekanan dan kesempatan yang tercipta dalam lingkungan kerjanya. Setiap individu yang masuk dalam perusahaan juga membawa dalam dirinya elemen-elemen perilaku yang melekat baik berupa cara berpikir, budaya, etika dan nilai-nilai moral tersendiri.

\section{Insentif/Tekanan (Incentives/Pressures)}

Faktor-faktor yang secara signifikan mempengaruhi seseorang dalam melakukan kecurangan terutama disebabkan oleh posisi perusahaan dan perorangan, struktur perencanaan kompensasi dan harapan-harapan eksternal. Model kecurangan tradisional mengatakan bahwa tekanan, baik berupa persepsi atau nyata, meningkatkan hasrat seseorang untuk melakukan kecurangan. 
Posisi Personal. Banyak kasus kecurangan yang disebabkan oleh penerapan kompensasi eksekutif. Menghubungkan kinerja perusahaan dengan insentif yang akan diperoleh eksekutif dipraktekkan secara umum oleh banyak perusahaan. Seorang eksekutif perusahaan atau karyawan dalam perusahaan dapat merasa sangat tertekan ketika kesuksesan perusahaan berhubungan langsung dengan rencana kompensasi yang akan dia peroleh. Bernie Ebbers, CEO WorldCom, yang menerima gaji pokok sebanyak $\$ 935,000$ pada tahun 1997, yang pada periode yang sama dapat membeli saham perusahaan melalui pinjaman perusahaan dengan total $\$ 409$ juta. Dengan demikian para CEO dapat lebih memperhatikan harga saham dibanding mengelola perusahaan secara keseluruhan. Pengelolaan harga saham dapat menjadi pengelolaan keuangan secara curang. Dalam model kecurangan traditional posisi personal ini yang didefinisikan sebagai tekanan. Individu dalam perusahaan terutama personal manajemen akan merasa tertekan ketika status keuangan pribadinya dalam kondisi yang sedang terpuruk. Adanya hutang pribadi yang harus dilunasi dapat sangat mempengaruhi seseorang untuk melakukan berbagai macam kecurangan dalam perusahaan.

Posisi Perusahaan. Hutang membuat eksekutif perusahaan tertekan tidak hanya untuk mendapatkan laba yang tinggi tetapi juga untuk melaporkan laba untuk menutupi hutang dan kewajiban lainnya. Posisi keuangan perusahaan sebagian besar dipengaruhi oleh kenerja masa lalu dan tingkat pertumbuhan yang direncanakan untuk dicapai oleh perusahaan. Sebagaian besar perusahaan yang melakukan kecurangan dalam beberapa tahun terakhir memiliki jumlah hutang dan leverage yang besar. Pada tahun 2000, derivatif WorldCom yang berhubungan dengan kewajiban meningkat dari \$ 1.8 miliar pada tahun sebelumnya menjadi $\$ 10.5$ miliar. Hal yang sama terjadi pada WorldCom yang mencatat hutang sebanyak \$100 miliar pada saat dinyatakan bangkrut. Pada tahun 2002 sendiri, menurut Portland Business Journal, 2003, terdapat 186 perusahaan publik yang dinyatakan bankrut dengan total aset sebanyak \$ 368 miliar.

Ketika perusahaan mengalami penurunan kinerja, pemilik akan mengharapkan hasil yang sama ketika perusahaan sedang mengalami kinerja baik tanpa merubah model dan tindakan manajemen. Jika manajemen tidak 
dapat mengindentifikasi alasan kesuksesan mereka secara benar pada periodeperiode sebelumnya, manajemen akan salah mengasumsikan bahwa metode yang digunakan sebelumnya masih tetap akan dapat berfungsi untuk mendorong kemajuan perusahaan. Jika kondisi ekonomi sedang menurun, maka para pemimpin perusahaan akan merasa semakin tertekan sehingga tekanan ini menjadi kontribusi yang mendorong perilaku kecurangan dalam perusahaan.

Ekspektasi Eksternal. Dewan komisaris perusahaan dan manajemen menggunakan metrik sebagai alternatif untuk melihat kenerja perusahaan, yaitu dengan menggunakan perbandingan harga saham perusahaan-perusahaan yang sama sebagai pengukuran kinerja aktual perusahaan mereka. Insentif berbasis saham ini mengandung tekanan sebagai akibat ekspektasi analis saham. Tekanan yang berasal dari pihak luar perusahaan dapat berupa harapan akan kinerja perusahaan oleh individu maupun perusahaan yang berada di luar lingkungan perusahaan, baik masyarakat, analis atau yang disebabkan oleh kompetisi pasar yang ketat. Setiap kuartal, analis memprediksi laba persaham (earnings per share - EPS). Prediksi ini sendiri akan mendorong pergerakan harga saham. Eksekutif mengetahui bahwa terdapat pinalti dari setiap penurunan harga saham, yang akan mengakibatkan jatuhnya harga saham perusahaan.

\section{Peluang (Opportunities)}

Efektivitas pengendalian akan mengurangi niat untuk menciptakan kesempatan pelaku melakukan aktivitasnya. Peluang yang meningkat akan meningkatkan niat untuk melakukan kecurangan. Peluang ini dapat berupa pengendalian internal perusahaan atau pengawasan eksternal, dan kompleksitas lingkungan dan hubungan antar pihak yang mempunyai kepentingan dengan perusahaan, terutama yang mempunyai kepentingan terhadap perusahaan.

Pengendalian Internal. Perusahaan akan membuka kesempatan kepada individu untuk melakukan kecurangan jika pengendalian internal seperti mekanisme pengesahan dokumen, kendali aksesibilitas, metode peninjauan (reviews) lemah. Salah satu tujuan dari dewan direktur adalah untuk menjaga tingkat pengambilan keputusan dalam perusahaan. Pengendalian internal termasuk lingkungan pengendalian intern, aktivitas pengendalian internal, tingkat 
pengawasan oleh komisaris dan direktur, komite audit dan kemite remunerasi. Dewan direktur merupakan elemen penting dalam pengendalian internal dan dipersepsikan sebagai pengendali akhir oleh pemegang saham. Seorang direktur yang gagal menjalankan tanggung jawab proses pengendalian perusahaan dengan tidak membiarkan eksekutif atau manajemen menjalankan operasi perusahaan tanpa hasil yang memadai. Tetapi banyak perusahaan yang melakukan kecurangan memiliki eksekutif agresif melanggar ketentuan yang ditetapkan oleh perusahaan, akibatnya pengawasan menjadi tidak berjalan dan perusahaan mengalami kejatuhan, seperti yang dilakukan oleh dewan komisaris WorldCom yang tidak dapat mengendalikan pembiayaan personal eksekutifnya hingga terjadi kecurangan dalam perusahaan.

Kompleksitas Lingkungan. Perusahaan atau divisi yang kompleks dalam perusahaan memberi kesempatan kepada direktur dan karyawan untuk menyembunyikan aktivitas kecurangannya, dan pihak-pihak lain yang berhubungan dapat membuat transaksi kecurangan semakin tidak dapat ditelusuri. Persepsi peluang untuk melakukan kecurangan dipengaruhi oleh kompleksitas lingkungan pekerjaan individu dan hubungan antar entitas bisnis dalam perusahaan. Semakin tinggi tingkat kompleksitas pekerjaan individu, semakin sulit bagi auditor, dewan komisaris dan badan otoritas untuk mengerti laporan keuangan perusahaan.

Hubungan antar pihak dalam perusahaan harus diuji oleh auditor untuk menentukan apakah mereka membuka peluang untuk melakukan kecurangan atau tidak. Hubungan dengan institusi keuangan dan pemegang obligasi juga penting untuk diselidiki karena keduanya dapat digunakan oleh perusahaan untuk melakukan kecuranganKompleksitas lingkungan dan pihak yang berkepentingan dapat dilihat pada kasus WorldCom. WorldCom mempunyai struktur perusahaan yang sangat kompleks untuk menyembunyikan kecurangan dan kerugian, dan tetap menjaga tampilan perusahaan sebagai perusahaan yang sukses.

Pengawasan Eksternal. Pengawasan eksternal termasuk perusahaan audit eksternal, pemerintah atau institusi dan perorangan lain yang berhubungan dengan perusahaan. Kantor akuntan publik dapat saja melakukan audit untuk 
mempertahankan hubungan baik dengan perusahaan dengan tujuan dapat menjual jasa konsultasi lebih banyak. Pertumbuhan jasa konsultasi umumnya lebih mudah dilakukan dengan menjualnya kepada klien audit yang sudah ada dibanding dengan menjualnya kepada klien baru. Pembayaran (fee) audit biasanya lebih kecil dibandingkan dengan pembayaran konsultasi untuk klien yang sama, yang menyebabkan terjadinya konflik kepentingan auditor antara independensi dan peningkatan keuntungan. Jasa alternatif yang dapat diberikan oleh seorang auditor ini menyebabkan menurunnya fokus seorang auditor antara menjadi konsultan bisnis atau menjadi seorang auditor.

\section{Sikap/Rasionalisasi (Attitudes/Rationalization)}

Rasionalisasi diukur dengan kemampuan seseorang untuk membela diri, menjelaskan atau dengan membuat pengecualian atas perilaku kecurangan yang dilakukannya. Peningkatan kemampuan untuk merasionalisasi juga akan meningkatkan kemungkinan bahwa orang akan melakukan kecurangan. Ketika seseorang berperilaku jujur, tidak dibutuhkan rasionalisasi atau pembuatan pengecualian. Sikap (attitude) merupakan presepsi seseorang dalam dirinya tentang suatu fenomena yang mendorongnya untuk berperilaku tertentu. Perekrutan orang-orang yang jujur oleh perusahaan dapat mengurangi perilaku kecurangan.

Kebutuhan untuk Sukses. Sikap seseorang terhadap perilakunya sendiri diprediksi oleh kerangka ekspektasi nilai yaitu keinginan untuk mencapai suatu hasil akan dipertimbangkan berdasarkan kemungkinan terwujudnya hasil tersebut. Orang yang tidak mempunyai etika mempunyai kecenderungan lebih besar untuk melakukan kecurangan, terutama jika terdapat tekanan dan peluang. Orang dengan kebutuhan yang lebih besar untuk dicapai mempertimbangkan kontribusi dan partisipasinya dalam kesuksesan sebagai sesuatu yang penting dan akan menikmati bekerja keras sebagai suatu tantangan. Pekerja keras ini akan merasa bahwa diri mereka adalah orang yang ahli dan di atas dari orang lain. Individu dengan kebutuhan untuk sukses tinggi akan mempunyai kemampuan untuk merasionalisasikan kecurangan jika mereka mendapatkan 
peluang dan tekanan yang hebat. Tipe individu ini dapat merasionalisasi kecurangan keuangan menjadi seperti sebuah sukses perusahaan.

Lingkungan Sosial. Norma sosial diprediksi oleh pelaku melalui ekspektasi terhadap pertimbangan orang lain dengan motivasi untuk menyesuaian diri dengan ekspektasi tersebut. Seseorang dapat saja merupakan individu yang jujur atau tidak jujur yang tergantung pada situasi yang dihadapinya, tetapi kebanyakan orang dipengaruhi oleh nilai-nilai etis yang terdapat pada lingkungannya. Perusahaan dengan kode etik yang kuat akan didukung oleh kebijakan, nilai etika dan pengukurannya berasal dari umpan balik yang dipandu oleh etika lingkungan yang kuat.

Persepsi atas Tindakan. Niat tidak selalu cukup untuk melakukan sesuatu. Seseorang harus mempunyai kepercayaan dan sumber daya untuk melaksanakan niat tersebut. Niat untuk berbuat curang dapat dibatasi oleh keraguan tentang kemampuan dan kepercayaan dirinya untuk melakukannya. Orang dapat melakukan kejahatan kecurangan karena pelaku menanamkan dalam dirinya bahwa dia mampu mengendalikan perbuatannya. Kesadaran itu dapat muncul karena pelaku telah menginternalisasi informasi bahwa tidak ada orang lain yang memiliki kapasitas atau pengetahuan untuk mendeteksi perilaku ilegal yang dilakukannya. Pelaku akan menjadikan sasaran orang-orang yang lebih tua, kurang berpendidikan, atau orang asing karena mereka tidak memiliki cukup kapasitas untuk mengetahui kecurangan. Pada saat pelaku kecurangan mengetahui bahwa auditor dan badan otoritas lainnya tidak dapat menangkap mereka, maka persepsi peluang kecurangan akan meningkat. 


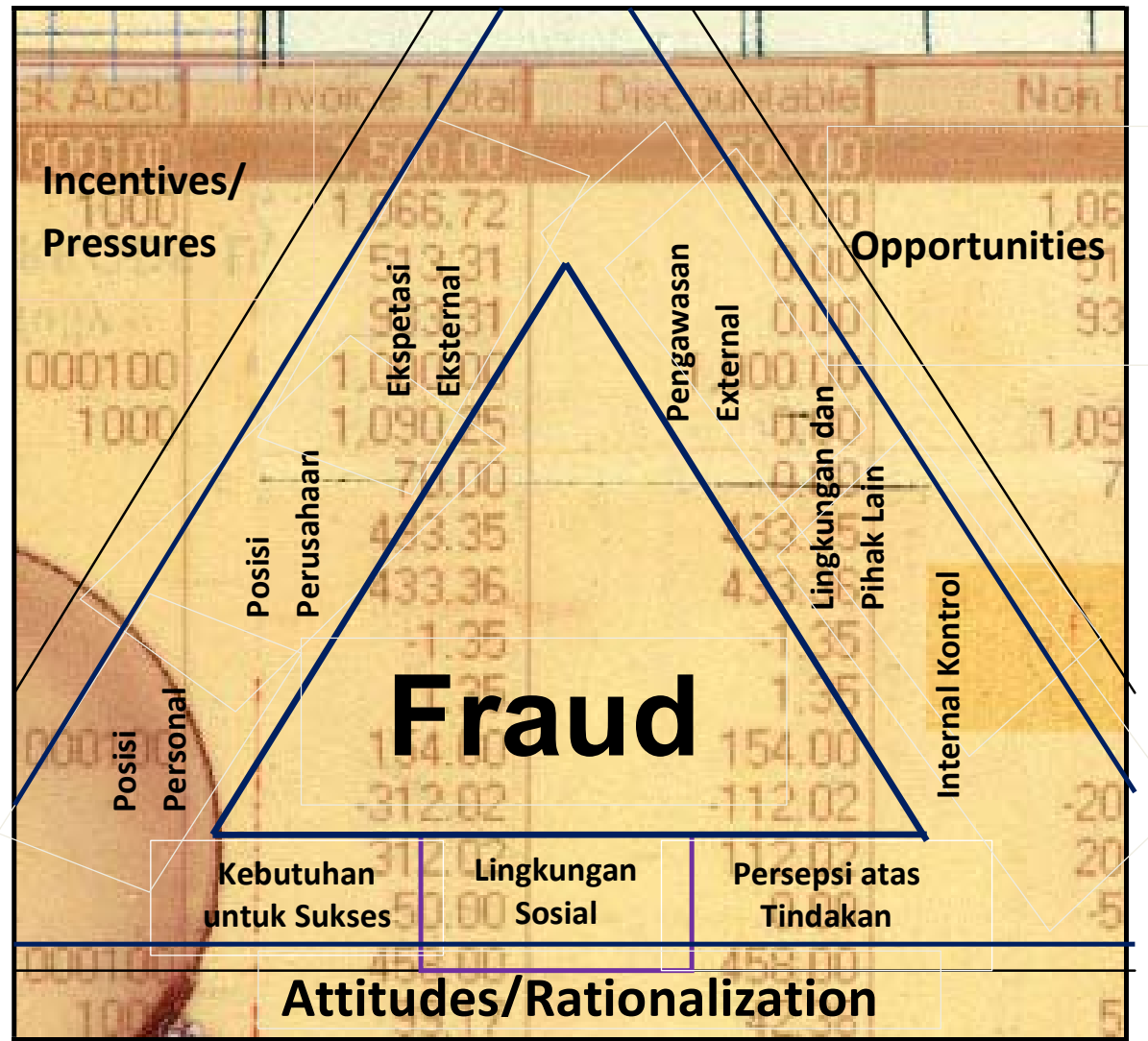

Gambar 2 : Fraud Triangle yang Dimodifikasi

\section{Unsur Perilaku Dalam Kecurangan Laporan Keuangan}

Investor menggunakan informasi keuangan untuk menilai hasil operasi perusahaan, mengambil keputusan tentang kinerja masa depan dan mengevaluasi faktor-faktor non-akuntansi dalam kerangka yang berhubungan dengan makro ekonomi dan model keuangan perusahaan yang mungkin dilakukan untuk investasi. Salah satu resiko terbesar yang dihadapi investor adalah resiko bahwa keputusah diambil berdasarkan informasi keuangan yang mengandung salah saji material. Informasi keuangan mungkin terjadi secara tidak disengaja (erroneously) atau karena kesengajaan (intentionally). Jika informasi keuangan salah saji karena suatu skema, dibuat atau diciptakan dengan maksud menyesatkan investor, maka bentuk ini disebut sebagai kecurangan pelaporan keuangan.

Indikator penilaian informasi keuangan tentang nilai-nilai pontensial perusahaan dapat juga dilihat dari informasi tentang penerimaan konsumen atas 
produk dan jasa, pangsa pasar, faktor-faktor kompetitif termasuk kekayaan intelektual, kualitas manajemen, basis-basis konsumen, distribusi sumber daya perusahaan, dan keuntungan secara sistem dan teknologi. Indicator-indikator nilai ini diproksikan dengan hasil operasi, di mana perusahaan diharapkan untuk menghasilkan peningkatan nilai ekuitas sekuritas oleh karena kemampuan dasarnya untuk menciptakan pertumbuhan pendapatan, pengendalian biaya, pencapaian profit margin dan peningkatan profitabilitas. Resiko merupakan faktor yang terdapat dalam investasi ekuitas. Resiko mendasar dalam investasi yaitu bahwa hasil pada masa depan, dalam hubungannya dengan operasi, profitabilitas dan nilai saham, tidak sesuai dengan hasil yang diharapkan. Resiko juga berhubungan dengan perubahan pendapatan atau dengan ukuran akuntansi lainnya.

Eksekutif perusahaan akan selalu berusaha untuk mereduksi resiko dengan memperlihatkan kinerja perusahaan yang meningkat secara terus menerus. Pemenuhan pencapaian kinerja perusahaan yang ditargetkan ini membuat eksekutif melakukan berbagai upaya untuk mencapainya dan pada saat yang sama berusaha untuk mendapatkan keuntungan pribadi dalam bentuk remunerasi dan penghargaan lain, reputasi dan prestise dari perusahaan dan masyarakat umum. Upaya pencapaian target tersebut melahirkan berbagai skema yang tidak saja secara strategis sesuai dengan aturan akuntansi tetapi juga melalui berbagai skema kecurangan pelaporan keuangan.

\section{Faktor-faktor Motivasi Perilaku Kecurangan}

Ketika menghadapi situasi tersedianya, stimuli eksternal untuk melakukan kecurangan yaitu insentif/tekanan dan peluang, maka seseorang akan mempertimbangkan akibat yang mungkin diperolehnya, yang dapat berupa keuntungan keuangan atau status sosial. Dari ketiga kasus yang dibahas dalam tulisan ini, semuanya menampakkan bahwa CEO cenderung melakukan kecurangan pelaporan keuangan agar terlihat lebih baik oleh pihak eksternal, menaikkan harga saham dan akhirnya menerima "kompensasi" dari hasil kecurangan mereka. ISA No. 240 menyebut insentif/tekanan sebagai "excessive pressure....to meet the requirement or expectations ofthird parties due to...trend level expectations of...analysts" sedangkan sikap/rasionalisasi disebut sebagai 
"a practice by management of committing to analysts...to achieve aggressive or unrealistic forecasts". Paragraf pertama di atas menunjukkan bahwa pressure dilakukan oleh analis, sedangkang yang kedua menunjukkan pada attitude yang dilakukan oleh manajer atau untuk menerima pressure. Dengan kata lain, insentif ekternal menjadi insentif internal terjadi hanya jika diinternalisasi oleh individu. Internalisasi didasarkan pada sikap, nilai dan kepercayaan.

\section{Elemen-elemen Perilaku Kecurangan berdasarkan Fraud Triangle}

Elemen insentif/tekanan (insentive/pressure) yang mendorong seseorang melakukan kecurangan didorong oleh hal-hal sebagai berikut:

1. Adanya bagian kompensasi tertentu kepada eksekutif yang dijanjikan oleh perusahaan jika mereka dapat mencapai target tertentu dalam harga saham

2. Kebutuhan untuk mendapatkan pinjaman atau ekuitas pembiayaan untuk tetap bertahan dalam bisnis yang kompetitif

3. Profitabilitas dan tingkat investas yang diharapkan oleh analis investasi, kreditor dan pihak luar

4. Kompetisi yang ketat dalam bisnis.

Elemen peluang (opportunites) menyajikan unsur-unsur faktor resiko yang dimanfaatkan oleh eksekutif, karena:

1. Kemudahan bertransaksi karena kelompok eksekutif merepakan orangorang dekat CEO

2. Adanya kompleksitas transaksi

3. Kegagalan auditor internal untuk mendeteksi kecurangan dalam perusahaan.

Komponen sikap/rasionalisasi (attitude/rationalization) yang dicerminkan oleh perilaku yang muncul dari diri pelaku sendiri. Alasan tersebut dapat berupa:

1. Manajemen mempunyai keinginan yang berlebihan untuk mempertahankan bahkan menigkatkan harga saham entitas dan laba, yang diperlihatkan oleh kompensasi opsi saham yang diberikan kepada 
eksekutif (WorldCom). Temuan ini sejalan dengan temuan Coffe, 2005, yang mengatakan bahwa "when one pays the CEO with stock Options, one create incentive for short-term financial manipulation and accounting gamesmanship".

2. Kinerja yang agresif dan prediksi yang tidak realistik yang dilakukan manajemen untuk mencapai ekspektasi analis, kreditor, dan pihak ketiga lainnya (Adelphia Communications).

3. Ketidakmampuan membedakan antara transaksi bisnis dan transaksi personal. Dari ketiga sampel di atas, dapat intrepretasikan bahwa transaksi seperti ini terutama dapat terjadi atas perusahaan-perusahaan yang kepemilikan dan pengelolaan perusahaan didominasi oleh individu atau kelompok yang sama, seperti yang terjadi pada Tyco International. Faktor resiko ini, dalam ISA 240 dapat dikategorikan sebagai kasus salah saji aset. Bahkan, manajemen Tyco menggunakan sumber daya perusahaan untuk membayar biaya pribadi manajemennya. Di Adelphia Communications, kecurangan terjadi atas penggunaan dana perusahaan untuk kepentingan pribadi keluarga Rigas, yaitu untuk membeli saham dan kondominium mewah di Mexico, Colorado dan New York City, serta untuk membangun lapangan golf. Selain itu, Rigas juga membeli hak pengelolaan hutan di Pennsylvania.

Elemen-elemen Perilaku Kecurangan berdasarkan Teori Fraud Triangle

\begin{tabular}{|c|c|c|}
\hline $\begin{array}{l}\text { Elemen-elemen } \\
\text { Segitiga Kecurangan }\end{array}$ & $\begin{array}{l}\text { Faktor-faktor Resiko Kecurangan } \\
\text { berdasarkan Teori Fraud Triangle }\end{array}$ & $\begin{array}{l}\text { Perusahaan yang } \\
\text { Terlibat }\end{array}$ \\
\hline Incentives/Pressures & $\begin{array}{l}\text { Kompetisi yang ketat atau pasar } \\
\text { yang jenuh } \\
\text { Profitabilitas atau meningkatnya } \\
\text { tingkat ekspektasi analis } \\
\text { investasi, badan investasi, } \\
\text { kreditur } \\
\text { Kebutuhan akan pinjaman atau } \\
\text { ekuitas keuangan untuk tetap } \\
\text { kompetitif } \\
\text { Terdapat bagian kompensasi } \\
\text { atas pencapaian target harga }\end{array}$ & $\begin{array}{l}\text { JR-Adelphia } \\
\text { JR-Adelphia, } \\
\text { BE-WorldCom } \\
\text { DK-Tyco } \\
\text { JR-Adelphia } \\
\text { BE-WorldCom }\end{array}$ \\
\hline
\end{tabular}




\begin{tabular}{|c|c|c|}
\hline & $\begin{array}{l}\text { saham, hasil operasi, posisi } \\
\text { keuangan dan arus kas }\end{array}$ & \\
\hline Opportunities & $\begin{array}{l}\text { Terdapat transaksi antar pihak } \\
\text { yang bukan transaksi normal } \\
\text { Dominasi manajemen oleh satu } \\
\text { orang atau kelompok kecil } \\
\text { Ketidakefektifan dewan } \\
\text { komisaris, komite audit dan } \\
\text { pengendalian internal }\end{array}$ & $\begin{array}{l}\text { DK-Tyco } \\
\text { JK-Adelphia, } \\
\text { DK-Tyco, } \\
\text { BE-WorldCom } \\
\\
\text { JR-Adelphia } \\
\text { DK-Tyco } \\
\text { BE-WorldCom }\end{array}$ \\
\hline $\begin{array}{c}\text { Attitudes/ } \\
\text { Rationalizations }\end{array}$ & $\begin{array}{c}\text { Kepentingan berlebihan oleh } \\
\text { manajemen meningkatkan harga } \\
\text { saham entitas atau laba } \\
\text { Intensi untuk mencapai kinerja } \\
\text { yang tinggi dan prediksi yang } \\
\text { tidak realistik } \\
\text { Pemilik - manajemen tidak } \\
\text { membuat perbedaan antara } \\
\text { transaksi personal dan bisnis }\end{array}$ & $\begin{array}{l}\text { BE-WorldCom } \\
\text { JR-Adelphia } \\
\text { JR-Adelphia, } \\
\text { DK-Tyco }\end{array}$ \\
\hline
\end{tabular}

Ket: JR = John Rigas, DK = Dennis Kowzlowski, BE = Bernard Ebbers

\section{Pengendalian Kecurangan dalam Perusahaan}

Tingkat resiko kejahatan yang berasal dari kecurangan korporasi, harus diantisipasi melalui manajemen resiko kecurangan yang konstan sepanjang waktu dalam organisasi. Meskipun resiko kecurangan laporan keuangan tidak dapat dieliminasi secara total, tetapi resiko itu dapat dibatasi melalui tindakan pencegahan:

1. Untuk mengurangi tekanan dalam kecurangan laporan keuangan, manajemen harus menentukan target kenerja perusahaan yang rasional, menurunkan tekanan eksternal melalui analisis ulang pendapat analis pasar yang sesuai dengan kondisi perusahaan dan industri, mengidentifikasi hambatan operasional perusahaan yang menghalangi kinerja keuangan dengan mengendalikan anggaran modal dan persediaan, serta membuat prosedur-prosedur akuntansi yang jelas dan 
seragam tanpa pengecualian transaksi tertentu. Kompensasi eksekutif harus ditentukan sewajarnya dengan membatasi insentif terhadap pencapaian target eksekutif sehingga pencapaian kinerja tidak menjadi motivasi eksekutif untuk berperilaku serakah.

2. Unsur-unsur resiko kecurangan yang terdapat dalam standar operasional perusahaan dan standar auditing harus ditambahkan dengan faktor-faktor pengintregrasian dan penilaian sikap eksekutif dan karyawan untuk mengidentifikasi motivasi personal yang atas target kinerja perusahaan yang ditetapkan. Penggunaan komponen teori planned behavior akan membantu auditor untuk menilai pengaruh etika personal, lingkungan dan tingkat kendali diri masing-masing individu dalam perusahaan.

3. Potensi perilaku eksekutif dan karyawan harus diantisipasi oleh perusahaan dengan melakukan proses perekrutan dan pengangkatan eksekutif melalui kehati-hatian dalam proses seleksi. Perusahaan harus merekrut karyawan yang mempunyai nilai moral yang tidak akan menimbulkan masalah dalam perusahaan. Nilai-nilai moral pribadi juga harus terus-menerus ditingkatkan melalui pelatihan sumberdaya manusia yang diberikan secara berkala kepada semua tingkat dalam perusahaan. Hal ini penting untuk memelihara intensi manajemen untuk mencapai tujuan perusahaan dengan niat yang benar. Standar auditing harus mengintegrasikan aspek-aspek psikologi secara lebih baik dengan menambahkan lebih banyak faktor-faktor perilaku dalam standar internal dan eksternal auditing. Sikap tersebut menyangkut kemampuan mengendalikan diri, gaya hidup, gaya kepemimpinan atau ambisi pribadi serta ketergantungan pada hal-hal tertentu.

\section{Kesimpulan}

Kecurangan tidak mungkin dieliminasi hingga nol persen dalam perusahaan, karena juga menyangkut dorongan kepribadian perorangan, Tetapi, dengan mengerti penyebab utama kemerosotan etika yang dilakukan oleh perusahaan-perusahaan tertentu, maka pemilik perusahaan di Indonesia dapat mempersiapkan diri untuk menghindari penurunan etika yang sama. Akhirnya, setiap individu dapat belajar dari kesalahan yang terjadi pada individu lainnya, 
demikian juga dengan unit bisnis dapat belajar dari kesalahan unit bisnis lainnya dan menghindari kesalahan yang sama untuk dilakukannya.

Perilaku curang yang ditunjukkan pada tingkat eksekutif telah menghancurkan banyak perusahaan dan karir para eksekutif perusahaan itu sendiri. John Rigas dari Adelphia, Bernie Ebbers dari WorldCom dan Dennis Kozlowski merupakan tiga dari banyak pemimpin perusahaan yang memberikan peringatan kepada pemilik perusahaan untuk menata ulang sistem yang telah ada dalam perusahaan. Mereka ini merupakan representasi dari eksekutif perusahaan yang menyalahgunakan kekuasaannya dengan melakukan kecurangan korporasi. Kesimpulan yang dapat ditarik dari tiga perusahaan yang diteliti adalah sebagai berikut:

1. Faktor-faktor yang mendorong eksekutif untuk melakukan kecurangan terutama dipengaruhi oleh tekanan eksternal untuk mencapai sasaran keuangan, dan pemenuhan ekspektasi analis pasar. Tekanan lainnya berasal dari internal perusahaan berupa mencapaian kinerja tertentu yang ditentukan pemilik perusahaan serta intensi eksekutif atas kompensasi dan insentif yang dijanjikan oleh pemegang saham. Posisinya untuk mengendalikan dan berkuasa sepenuhnya atas operasi perusahaan membuka kesempatan kepada eksekutif untuk memanipulasi laba dan pencapaian target yang ditentukan pemilik perusahaan. Kecurangan ini akan semakin dipermudah jika perusahaan melakukan transaksi dengan pihak-pihak yang berhubungan dekat dengan eksekutif, oleh karena itu pengawasan dari pihak di luar perusahaan diperlukan terus menerus untuk mengendalikan perilaku keserakahan yang dapat muncul dari perseorangan dalam perusahaan maupun intensi perusahaan untuk mempertahankan reputasinya dengan melanggar peraturan di bidang keuangan.

2. Berdasarkan teori fraud triangle, eksekutif terdorong untuk melakukan kecurangan terutama karena adanya kesempatan untuk memperoleh kompensasi tertentu jika dapat mencapai target tertentu, pemenuhan ekspektasi pasar dan kebutuhan untuk mendapatkan pinjaman menjadi pendorong eksekutif untuk melakukan manipulasi pendapatan. Peluang untuk melakukan manipulasi pendapatan dipermudah oleh posisi pelaku kecurangan yang berada pada puncak pimpinan perusahaan sehingga 
pengendalian internalnya tidak dapat berfungsi secara baik. Eksekutif kemudian akan merasionalisasi kecurangan yang dilakukannya dengan menggunakan alasan pencapaian target perusahaan dan kompensasi yang diperoleh merupakan konsekuensi atas prestasi yang dicapai.

3. Perilaku kecurangan berdasarkan teori planned behavior dapat digunakan untuk menjelaskan kecurangan dengan menelusuri unsur-unsur kepribadian para pelaku kecurangan. Sikap untuk berperilaku curang dapat saja muncul karena kepribadian eksekutif yang cenderung hidup secara berlebihan, gaya kepemimpinan yang sangat dominan dan bersifat tirani atau kegemaran secara pribadi dan pengaruh subjektif yang berasal dari orang-orang di sekeliling eksekutif tersebut.

Materi yang digunakan dalam penelitian ini diseleksi seteliti mungkin, namun demikian, mungkin terdapat motif lain dari pelaku kecurangan seperti usaha pelaku untuk memperlihatkan kekuasaannya dalam perusahaan. Model yang dikembangkan dalam penelitian ini juga memerlukan tambahan perspektif lainnya yang dibutuhkan oleh praktisi dan perancang sistem yang berhubugan dengan pencegahan dan pendeteksian kecurangan sebagai kerangka untuk mengembangkan elemen-elemen dan motivasi kecurangan keuangan. Juga dibutuhkan studi empiris yang behubungan dengan pengujian terhadap model ini, dan mengembangkan kerangka yang lebih mudah untuk mengkuantifikasi resiko organisasi untuk menghadapi kecurangan. 


\section{DAFTAR PUSTAKA}

AICPA, 2002, Generally Accepted Auditing Standards No. 316, Consideration of Fraud in a Financial Statement Audit, New York.

Bandura, A., 1999, Moral Disangagement in Perpetration of Inhumaties, Personality and Social Psychology Review, 3: 193-209.

Bergstresser, Daniel and Thomas Philippon, 2004, CEO Incentives and Earnings Management, Harvard Business School, Boston.

Bergstrom, B. 2002, Analysts think putting Rigases in back seat would help Adelphia, The (Olean) Times Herald (May 23): A-1.

BusinessWeek, 2002, The Rise and Fall of Dennis Kozlowski: How did he become so unhinged by greed? A revealing look at the man behind the Tyco scandal, December 23.

Business Wire, October 21, 2002, Cable Companies Announce Common Operating Statistics; Chief Executives Pledge Corporate Support of Initiative, LexisNexis, November 12, 2002.

Cressey, D.R., 1953, Other People Money: A Study in the Social Psychology of Embezzlement, The Free Press, Illinois. Dalam Singleton, 2006, Fraud Auditing and Forensic Accounting, Third Edition, John Wiley \& Sons, New Jersey, hal. 9.

Efendi,J., A. Srivastava and E. Swanson, Why Do Corporate Managers Misstate Finance Statement? The Role of Option Compensation and Other Factors, Journal of Financial Economics, 85(3), 667-708, 2005.

Gillett, P. R. and Uddin, N., 2005, CFO Intentions of Fraudulent Financial Reporting, Auditing: A Journal of Practice and Theory, 24 (1), 55 - 75.

Lieberman, D., 2002, SEC filing reveals Rigases' use of Adelphia's assets, USA Today, May 28.

Magnan, Michel, Denis Cormier and Pascale Lapointe-Antunes, 2008, Like Moths Attracted to Flames: Executives and Financial Reporting Frauds, Ontario.

Master, Brooke A., WorldCom's Ebbers Convicted: Jury Finds Former CEO Guilty on All Nine Counts, Washington Post, Wednesday, March 16, 2005; Page A01. 
Miller, G.S., 2006, The press as a Watchdog for Accounting Fraud, Journal of Accountancy Research, 44(5), 1101-1033.

Paton, Michael Quinn, 2002, Qualitative Research \& Evaluation Methods, Third Ed, Sage Publication, California.

Patsuris, Penelope, 2002. The Corporate Scandal Sheet, http://www.forbes.com/2002/07/25/accountingtracker.html , Akses 02 April 2009.

Securities and Exchange Commission, Form 10-K. 2 April 2001: http://www.sec.gov/Archives/edgar/data/796486/0000796486010000 12/0000796486-01-000012-0001.txt, Akses 15 September 2009.

Securities and Exchange Commission, 2002, Litigation Release No. 18147, May 19, Washington DC.

Securities and Exchange Commission, 2002, Litigation Release No. 17627, July 24, Washington DC.

Securities and Exchange Commission, 2002, Litigation Release No. 17722, September 12, Washington DC.

Securities and Exchange Commission,2003, Report of investigation by the special investigative committee of the board of directors of WorldCom, Inc. Washington, DC.

Sidak, J. Gregory, 2003, The Failure of Good Intentions: The WorldCom Fraud and the Collapse of American Telecommunications After Deregulation, Yale Journal on Regulation, Vol. 20:2.

Singleton, Tommie W, at al., 2006. Fraud Auditing and Forensic Accounting, Third Edition, John Wiley \& Sons, Inc., New Jersey.

Tuanakotta, Theodorus M, 2007. Akuntansi Forensik dan Audit Investigasi, LPFEUI, Jakarta.

Valli, Sarvani, 2009, Ten Major Accounting Scandals, http://bizcovering.com/history/10-major-accounting-scandals/ ,Akses 23 April 2009.

Wall Street Journal, 2007, Tyco Convictions Upheld, New York, N.Y., Nov. 16,hal. C.5.

Yang, C. and Brian Grow, 2005, What Did Ebbers Know?, BusinessWeek, January 14. 